\title{
P-0766- Insulin initiation in Nepalese patients with type 2 Diabetes : types, indications and outcomes
}

\author{
A. Joshi,P. Yonzon, R.Thapa, P. Dahal, Kathmandu Diabetes and Thyroid Center \\ Kathmandu, Nepal
}

Background Type 2 diabetes is the most common type of diabetes in adults and is characterized by both peripheral insulin resistance and impaired insulin secretion. Treatment of type 2 diabetes include education, lifestyle changes and oral medications to maintain good glycemic control. As the disease progresses with worsening hyperglycemia and deterioration in beta cell function and loss of beta cell mass most T2DM patients will eventually require insulin to reach glycemic target ${ }^{1}$. Most common indication of insulin initiation is when glycemic control has deteriorated despite maximally tolerated oral agents.

Aim

The aim of our study was to examine the following:

1. Indications for insulin initiation

2. Initial insulin regimen prescribed

3. Effect on glycemic control

Method

This was a prospective study conducted at an Endocrine Center in Kathmandu, Nepal . A total of 101 patients( 55 male and 101 female) with type 2 diabetes were enrolled in our study. Patients already on insulin use, not willing for insulin therapy and type 1 diabetic patients were excluded from this study. Baseline FBS, PP blood sugar and HbA1c were analyzed at the time of initiation and compared after 3 months using paired t test.

Results

In total 101 eligible adults ( 55 males, 46 females; mean age $55.02 \pm 12.7$; mean baseline HbA1c $10.68 \pm 3.44)$ initiated insulin. Premixed insulin (55.4\%) was the most common prescribed insulin followed by basal insulin (28.43\%) and basal bolus insulin (15.8\%). The most common indication of insulin initiation was poorly controlled diabetes $(72.2 \%)$ followed by high $\mathrm{HbA1C}$ at diagnosis (11.8\%), diabetes complications $8.9 \%$ and OHA failure $6.9 \%$. The mean HbA1c at 3 months follow up was $7.72 \pm 1.506$.

\section{Discussion}

In our study poorly controlled diabetes was the most common indication for insulin initiation and premixed insulin was the most common insulin prescribed insulin followed by basal insulin. Patients who were started on insulin therapy achieved good glycemic control at 3 months follow up.Treatment with insulin provides many benefits patients with type 2 diabetes. Patients failing to achieve glycemic goals with maximally tolerated anti hyperglycemic agents should be advised for insulin regimen ${ }^{2}$. Before initiating insulin, patient's eating, sleeping, exercise pattern and motivation for diabetes management should be carefully considered. With significant improvements in glycemic control the long term complications associated with exposure to chronic hyperglycemia can be minimized ${ }^{3}$

1. RG Bretzel, M.Eckhard, et al .Initiating Insulin Therapy in Type 2 Diabetic Patients failing on Oral Hypoglycemic Agents. Diabetes Care.2009 Nov;32(Suppl 2):S260-S265

2. SG.Swinnen, JB.Hoekstra et al. Insulin Therapy for type 2 Diabetes Care. 2009 Nov, 32( Suppl 2):S253-S259

3. IM Stratton et al. Association of glycemia with macrovascular and microvascular complications of type 2 diabetes( UKPDS 35): BMJ 2000;321:405

\begin{tabular}{|c|c|c|c|c|}
\hline & $\begin{array}{l}\text { dication for } \\
\text { ulin initiation }\end{array}$ & $\begin{array}{l}\text { Types of } \\
\text { insulin } \\
\text { prescribed }\end{array}$ & Initial $\mathrm{HbA} 1 \mathrm{c}$ & $\begin{array}{l}\mathrm{HbA1c} \text { at } 3 \\
\text { months follow } \\
\text { up }\end{array}$ \\
\hline $\begin{array}{l}0 \\
0 \\
0 \\
0\end{array}$ & $\begin{array}{l}\text { Poorly } \\
\text { controlled DM } \\
72.2 \% \text { ( } \\
73 / 101) \\
\text { OHA failure } \\
6.9 \%(7 / 101) \\
\text { High A1C at } \\
\text { diagnosis } \\
11.8 \% \\
(12 / 101) \\
\text { Complications } \\
8.9 \%(9 / 101)\end{array}$ & $\begin{array}{ll}\text { - } & \text { Basal } \\
& \text { insulin } \\
& 28.43 \% \\
& (29 / 101) \\
& \text { Premixed } \\
& \text { insulin } \\
& 55.4 \% \\
& (56 / 101) \\
\text { - } & \text { Basal } \\
& \text { bolus } \\
& \text { insulin } \\
& 15.8 \% \\
& (16 / 101)\end{array}$ & $10.68 \pm 3.44$ & $7.72 \pm 1.506$ \\
\hline
\end{tabular}

